\title{
El Apostolado a través de la protesión
}

\author{
por el Dr. JOSE ROSELL RIOS, (1) \\ Catedrático de la Facultad de Derecho, \\ de Ia Pontificia Universidad Católica.
}

1.-Colaboración en una profunda integración de la vida jurídica.El abogado por la índole de su profesión tiene una especial función que cumplir en la integración de la vida jurídica del Estado en que vive, pero, también, hay que tener presente que no siempre puede colaborar debidamente para ese fin, porque la realidad nos demuestra que las instituciones adolecen cada vez más de falta de ordenación jurídica recta, que no siempre somos los abogados los que legislamos y que tampoco, en todas las oportunidades, las normas jurídicas $\mathrm{y}$ el ordenamiento jurídico son respetados.

Frente a la situación descrita, la misión del abogado, en la integración de la vida jurídica de un país, se hace cada vez más ardua, más difícil. Esto no obstante no podemos dejar, no debemos dejar de proclamar y defender la justicia y el derecho.

Pero, ante la situación de hecho ya expuesta ¿Cómo puede el abogado colaborar en la integración de la vida jurídica del país?. Vamos a verlo: 1 , Cuando como legislador le toque sostener las instituciones jurídicas y propugnar la legislación de acuerdo con el Derecho, entendiéndose como tul el que está de acuerdo con el Derecho Natural o no es contrario al mismo. 2\%, Cuando como funcionario del Estado, llámese Magistrado o Assesor Legal u ocupe cualquier cargo público, defienda la organización jurídica recta y trate de amoldar sus actos a las normas del Derecho. 3\%, Cuando cumpliendo su función de Abogado propiamente dicha defiende el Derecho o por mejor decir respete el órden jurídico, lo que Sauer llama "la ley jurídica fundamental", lo que para nosotros es el Derecho Natural.

$Y$ aquí al tratar de la función del Abogado podemos enfocar el punto referente al objetivo del abogado: ¿Ganar el pleito? o ¿hacer efec.

(1) Palabras pronunciadas en el Colegio de Abogados, durante la Semana de Estudios, organizada con motivo del Congreso Eucarístico Nacional y Mariano (Diciembre de 1954). 
tiva la justicia? Si se insinúa incompatibilidad entre ambos términos, debemos decir que no la encontramos. En efecto, del eoncepto que tenemos de la función del abogado se deduce la respuesta.

La misión del abogado es obtener el triunfo de la Justicia, es decir que se dé a cada uno lo suyo. El abogado recto, el que es verdaderamente ABOGADO, sólo puede tomar para defenderlas causas que considere justas $\mathrm{y}$ hecho este presupuesto, su objetivo es ganar el pleito, sirviendo al cliente, persiguiendo en consecuencia el triunfo de la justicia, es decir hacerla efectiva.

No hay pues, ni puede haber incompatibilidad entre el servicio del cliente y el de la Justicia. El abogado que olvida esto no es abogado, pues la misión del abogado, como repito, es obtener el triunfo de la justicia, a través del proceso, de la defensa de su cliente.

Para terminar con este punto recordaré lo que dice Wilhelm Sauer (Filosofía Jurídica y Social), refiriéndose al abogado: "Ha de servir al cliente, pero dentro de los límites del Derecho; como sacerdote del Derecho, no puede aplicar medios indecorosos para conseguir la victoria de la parte a la cual defiende, no puede inducir a error al tribunal; en este sentido puede afirmarse que el abogado auxilia al tribunal. El juez, el fiscal, el abogado están subordinados a la misma norma, el orden jurídico, el interés del Estado, la ley jurídica fundamental".

Por eso, nuestro Código de Etica Profesional establece en su art. 1․, al iratar de la esencia del deber profesional que "El abogado es un servidor de la justicia $y$ un colaborador del juez en el recto ejercicio de sus funciones; la esencia de su deber profesional consiste, por tanto, en defender $y$ aconsejar a sus clientes con diligencia $y$ estricta sujeción a las normas jurídicas y morales en los asuntos que sean sometidos $\alpha$ su patrovinio o consulta".

2.-Labor efectiva $\mathrm{y}$ generosa en las asociacionos profesionales.El abogado que quiera darse a los demás, puede y debe actuar eficientemente en las asociaciones profesionales. No debe negar su colaboración efectivo a las mismas en cumplimiento de las comisiones que le sean encomendadas, en las conferencias o charlas en las que esté capacitado para intervenir y para las cuales se le haya solicitado su actuación.

El abogado no debe pensar sólo en el trabajo retribuído económicamente por legítimo que esto sea. Cucnto más antiguo, y más capaz es el profesional y mejor es sa situación económica, más eficiente puede $y$ debe ser su colaboración en las actividades de la vida institucional. Cuanto bien puede hacer un profesional versado colaborando en su institución me. diante charlas $y$ conferencias que hagan llegar sus conocimientos a otros colegas necesitados de cultura jurídica.

También, el abogado debe colaborar, cuando sea solicitado, en los ccnsultorios jurídicos gratuitos: sí es antiguo como consultor, si es joven como defensor. En el Consultorio Jurídico Gratuito de nuestro Colegio tenemos magníficos ejemplos de desinteresada colaboración profesioncl.

3.-Apostolado sobre el colega $\mathbf{Y}$ sobre el cliente.-Es el punto de acción máxima del abogado católico; y por qué no decirlo del Abogado 
propiamente tal. Es donde debe darse, entregarse, con el más amplio espíritu de caridad. El apostolado sobre el colega consiste en ayudarlo cuando necesita colaboración, desinteresadamente, $y$, luego, en no mirar al colega que defiende a la parte contraria como a un enemigo. Debe actuar con amplio espíritu de comprensión y prudencia en el recto sentido de la palabra.

Nuestro Código de Etica Profesional expresa que "Entre los abogados debe primar fraternidad que enaltezca la profesión y respeto recíproco, sin que influya en ellos la animaversión de las partes". Couture dice: "Sé leal para con el adversario, aun cuando él sea desleal contigo". (Los Mandamientos del Abogado).

El apostolado sobre el cliente puede hacerse efectivo enseñando $\alpha$ éste lo que es recto. Generalmente, el cliente se ofusca y hay que dominar esa ofuscación, hay que hacerle ver cuándo tiene razón y cuando no la tiene, y jamás explotor, o pretender explotar sus debilidades o errores.

Pero hay más aún, el abogado con verdadera vocación de tal no puede abandonar al cliente, no puede hacer cálculos económicos acerca del patrocinio, cuando angustiadamente solicitan su auxilio.

$Y$ esto depende de lo vocación: "La vocación no es un acto jurídico; no es una disposición positiva, una creación técnica, una herencia voluntaria. La vocación es un llamado que la verdad hace al espíritu humano, desde fuera y desde dentro, en no importa cuál acontecimiento de la vida de un hombre. Tener conciencia de esa manifestación, es conocer la existencia de la vocación, aunque no se conozcan sus caminos". (Sepich: Inzroducción a la Filosofía). 